\title{
(In)securitization and illiberal practices on the fringe of the EU
}

\author{
Dimitris Skleparis \\ Hellenic Foundation for European and Foreign Policy (ELIAMEP), Athens, Greece
}

\begin{abstract}
Illiberal practices of liberal regimes have been extensively studied by critical security studies. The literature on risk emphasises the idea of imminent dangers and the logic of worst-case scenarios, which eventually unsettle the balance between security and liberty by always favouring the former in its most coercive and exceptional forms. This paper, by drawing on (in)securitization theory, attempts to explain how particular illiberal practices with respect to the control and management of immigration on the fringe of the EU become normalised. It argues that (in)securitization of immigration and illiberal practices are effects of the very functioning of a transnational field of (in)security professionals that are produced through the structural competition between different actors of this field over the definition of security and the appropriate control and management of immigration. In this respect, it uses Greece as a case study and draws on material gathered through interviews with Greek security professionals in Athens, Lesvos, Orestiada, and Alexandroupoli, and analysis of their discourse in dissertations they prepared during their study in police academies.
\end{abstract}

\section{Introduction}

Liberal regimes have long resorted to illiberal practices of government, policing, and social control (Bigo et al. 2009). These practices include, but are not limited to, extraordinary rendition and return policies, indefinite detention of third-country nationals, new practices and technologies of border controls, the denial of due process and access to courts, conditions of quasi-isolation, torture, interception of private communications, restrictions on refugees and their confinement in camps and detention centres, disproportionate empowerment of executive powers, and extended powers of law enforcement agencies (Jabri 2006, p. 51, Tsoukala 2006, p. 607, Aradau 2008, p. 293, Basaran 2008, p. 339, Huysmans and Buonfino 2008, p. 771, Guild et al. 2009, p. 1). The literature on illiberal practices of liberal regimes has troubled the boundaries between security and law. In this respect, the (in)securitization theoretical framework ${ }^{1}$ has made a significant contribution to this literature by examining illiberal practices of liberal regimes as routinized banal day-to-day practices of the normal mode of government. These studies usually focus on Central and Western Europe, and North America. 
However, border control practices in Central and Western Europe dramatically differ from those employed at the external borders of the EU. In other words, the technologization of border management and surveillance at a distance in recent years has produced different effects in border control practices, on the one hand, in mainland EU and, on the other, at its fringes. Moreover, the technologization of border management and surveillance at a distance has affected differently security professionals across the EU. Hence, it is assumed that illiberal practices in immigration management and control at the fringes of the EU are becoming normalised by security professionals in a different way than in mainland EU. In this respect, this paper attempts to provide an understanding of how exceptionalism becomes engrained in ordinary law and the everyday routine work of security professionals at the external borders of the EU.

Thus, this paper uses the (in)securitization theoretical framework, and the (in)securitization process that took place in Greece in 2012 as a case study. Greece constitutes the ideal ground for applying the aforementioned theoretical framework, as the (in)securitization of immigration in the country is a complex and long process that has started to unfold since the country first became an immigration host in the early 1990s (Karyotis and Patrikios 2010, Karyotis 2012, Swarts and Karakatsanis 2012, Karyotis and Skleparis 2013). Additionally, the European Court of Human Rights has ruled against Greece, only in 2012, in several occasions on the grounds of the violation of the right to freedom from inhuman or degrading treatment. ${ }^{2}$ Within this context, a number of migrant protests have taken place in the country in recent years (see Karyotis and Skleparis 2014).

In this regard, 20 Greek security professionals from the Hellenic Police were interviewed in Athens, Lesvos, Orestiada, and Alexandroupoli in 2012, allocated by the Ministry of Public Order and Citizen Protection after a formal request was placed. Access to additional interviewees was gained through already established contacts, taking into consideration the requirement of expertise in immigration issues. The sample comprised male security professionals. ${ }^{3}$ Six of them were high rank officers, 46-60 years old, and 14 were low rank officers, 30-45 years old. Additionally, 12 masters' dissertations on immigration issues prepared by Greek elite ${ }^{4}$ security professionals during their study at the School of National Security and the Hellenic National Defence College were analysed. Access to these dissertations was granted after a formal request was submitted to the aforementioned institutions. Both institutions provide postgraduate education to senior members of the Hellenic Police, Armed Forces, Coast Guard, Fire Brigade, and civil servants of the broader public sector, who are responsible for state security issues. What makes these dissertations so important is the fact that they are produced by officials, who will most likely occupy the highest rank positions within their field.

\section{(In)securitization and illiberal practices}

Securitization studies focus on the ways in which security issues emerge, spread, and dissolve. It is an ever-growing and dynamic subfield of International Relations, comprised academics with interdisciplinary research agendas, contested theoretical underpinnings, and diverse methodological approaches. In its initial conception, securitization is defined as the outcome of a strategic process of interrelated discourses that result in the social construction of an issue as a threat (Buzan et al. 1998). In general terms, the securitization of an issue occurs when actors, speaking in the name of a referent object, 
succeed in convincing an empowering audience that the perceived seriousness of a threat, regardless of its objective significance, justifies the mobilisation of all available resources to curtail its development (Buzan et al. 1998). ${ }^{5}$

In principle, anyone could act as a securitizing actor. However, due to the fact that security "is a structured field" that involves a high degree of centralization and a low level of pluralism, certain actors are better placed to write legitimate security discourses (Buzan et al. 1998, p. 31). Thus, the most influential securitizing actors, with the required societal currency, know-how, and status, are usually political elites such as those in government (Waever 1995). Indeed, the role of political elites in the securitization of migration and asylum in Greece has been extensively documented by various scholars (see Karyotis 2012, Swarts and Karakatsanis 2012). However, the role of security professionals and EU institutions in securitization processes in the country has been somewhat neglected by these studies, mainly due to inherent deficiencies in the traditional securitization framework: its narrow focus on public discourses that excludes other potential forms of securitization, such as material practices, knowledge, and professional skills (see Huysmans 2004, 2006); and its one-dimensional focus on the securitizing actors that have the authority and are institutionally legitimate to perform a securitizing "speech act" (see Balzacq 2005, Karyotis and Patrikios 2010). Subsequently, these shortcomings have rendered impossible the study of security professionals' increasing reliance on illiberal practices that accompany the securitization of migration in Greece.

In contrast, a number of scholars (e.g. Bigo 2002, Bonditti 2004, Bigo and Guild 2005, Bigo and Tsoukala 2008) have moved away from the traditional definition of securitization as a "speech act", and have developed an understanding of securitization as a "field effect". This theoretical framework, which guides the analysis of this paper, is known as (in)securitization theory.

According to this framework, the field is a distinct social locus that is characterised by interdependent and diverse positions (Wacquant 1989, p. 39). It is a structured system of social positions, which are taken up either by individuals or institutions, the status of which determines the condition for the agents that occupy them (Jenkins 1992, p. 53). Depending on its defining content, each field is characterised by a different logic and structure of necessity and relevance, which both produces and is produced by the habitus that "inhabits" in the specific field (Jenkins 1992, p. 52). In this respect, the habitus of agents inclines the fields in which they move, their capacity to move in various fields, and the strategies they can employ (Williams 2007, p. 28). All in all, both the habitus and the field are in a reciprocal relationship, and by extension a relationship of power, that reproduces regularities of behaviour (Williams 2007, p. 28). However, neither the habitus nor the field are fixed, nor are they reproduced automatically; rather, they are continuously reinstated and transformed (Williams 2007, p. 27). They are "constantly evolving, dynamic terrains of struggles and change" (Leander 2009, p. 5), which, in the case of the field of (in)security, produce the very process of (in)securitization and illiberal practices (i.e. field effects).

A field is structured along three dimensions (Bourdieu 1998): first, the field is a field of forces that polarises the stakes of the agents that move therein, just like a magnetic field. It "supposes that the circulation of power/struggles has a centripetal relational force that attracts agents toward each other while maintaining their distinctive deviations as in a 'magnetic field"' (Bigo 2011, p. 239). This force is provided by specific stakes for which different agents struggle and needs to be stronger than the centrifugal one, which disperses 
individuals towards other stakes, while it sometimes allows some powerful agents of the field to exclude other agents from the game (Bigo 2011, p. 239). Second, the field is a field of struggles, which is defined by "the stakes which are at stake" (Jenkins 1992, p. 52). Indeed, the actors that move in a specific field do share the same interests and the same sense of the game - although, they may not always be conscious about it (habitus) which causes the struggles within the field. Finally, the field is a field of domination, which is comprised of unequal positions, where some elements dominate others.

According to this framework, the field of (in)security comprises (in)security professionals such as police officers, border control enforcers and, in some cases members of the army, who play a fundamental role in the (in)securitization of migration (Bigo 2002). In this approach, security is socially and politically constructed through the "struggles for political decisions and justification of practices of surveillance, control and punishment as well as practices of protection, reassurance, worrying and surveillance" (Bigo 2008b, p. 124). In this respect, security and insecurity are the outcomes of a process of "(in)securitisation" (Bigo 2008b, p. 124), which results from the structural competition between actors with different forms of capital, legitimacy, and interests, and their ability to protect their field and dominate it over the definition of security (Bigo and Tsoukala 2008, pp. 4, 5). Thus, (in)security and (in)securitization are field effects and not the outcomes of the strategy of a dominant actor (Bigo and Tsoukala 2008, pp. 4, 5). (In)securitization then, has to do with the day-to-day bureaucratic decisions of everyday politics, with routines of rationalisation, with various technological and technocratic practices, and with the security knowledge and relations between (in)security professionals (Bigo 2002, Huysmans 2006, Balzacq 2008).

The concept of risk plays a key role in the (in)securitization theoretical framework. Risk suggests the probability of harm, damage, or danger (Mythen and Walklate 2006). Bigo (2006b) has employed the notion of risk in order to bring attention to the routinized bureaucratic practices of (in)securitization of the managers of fear and unease that focus on risk management, or else, the proactive practices that aim to prevent the occurrence of dangers in the future. Often, these proactive practices are identified with the deployment of technologies (Aradau and Van Munster 2007, p. 108). The notion of imminent danger, which is part of the logic of risk and worst-case scenarios, "eventually unsettles the balance between security and liberty by always favouring security in its most coercive modes" as in this logic "any action is better than no action at all" (Bigo and Guittet 2011, p. 492). This "preventive dimension" embedded in risk management "generates suspicion and discretion, destabilizes our notions of privacy, freedom and democracy as well as presumption of innocence" (Bigo et al. 2009, see also Bigo 2012, p. 283). Risk, and more specifically precautionary risk, is the underlying rationale and legitimisation of the state's protective mandate and its utilization of exceptional practices (Aradau and Van Munster 2007, 2009, Donkin 2014). "Rather than the limit of normality, risk infuses exceptionalism within the governmentality of everydayness" (Aradau et al. 2008, p. 152); an exceptionalism that relegates the enemy/"Other" to "the category of cultural and even racial infrahumanity" (Aradau and Van Munster 2009, p. 693).

According to the (in)securitization framework then, illiberal practices are "the result of the very functioning of a solidly constituted security field of professionals of management of unease, both public and private, working together transnationally" (Bigo and Tsoukala 2008 , p. 4). (In)securitization theory offers an analysis of law and security as an everyday 
practice and an understanding of how liberal regimes exercise both liberal and illiberal practices. Indeed, liberal regimes have long resorted to illiberal practices of government, policing, and social control (Bigo et al. 2009), as "[l]iberal forms of governing are based not only on liberal, but also on illiberal practices that are engrained within it" (Balzacq et al. 2010, p. 9). In other words, "[w]e are indeed still in liberal regimes, dealing with, reproducing and hiding illiberal practices" (Bigo and Guittet 2011, p. 493). By extension, this indicates that the control of populations is routinized and that unequal access to fundamental rights is a defining characteristic of liberal states (Lippert and Williams 2012, p. 55).

Hence, illiberal practices result from the effects of the field of (in)security, which render them heterogeneous, globally incoherent, yet predictable in their local effects (Bigo and Tsoukala 2008, p. 4). Thus, exception is a result of routinized daily practices of security professionals (Bigo et al. 2010b, p. 5) and a form of governmentality of unease through worst-case scenarios (Bigo 2008a, p. 33) that makes illiberal security practices ordinary (Bigo 2006a, p. 47). All in all, "[e]xception works hand in hand with liberalism and gives the key to understanding its normal functioning, as soon as we avoid seeing exception as a sole matter of special laws" (Bigo 2008a, p. 33). Exception also works hand in hand with the deployment of prevention technologies as the sole response to a catastrophic future induced by flows of people across the world (Bigo et al. 2010b, p. 6).

\section{(In)securitization of migration and illiberal practices in Greece}

In 2012, the largest episode of (in)securitization of migration started to unfold in Greece. Operation "Aspida" ("Shield") at the Greek-Turkish land border, Operation "Xenios Zeus", which focused on inland detections of irregular stay, the building of new detention centres across Greece, the construction of a barbed wire fence at the $12.5-\mathrm{km}$-land border between Greece and Turkey and the extension of migrants' and asylum seekers' detention by up to 12 months, all constituted equally important elements of this episode.

Operation "Aspida" began on 2 August 2012. Its aim was to enhance border controls, surveillance, and patrols at the Greek-Turkish land border. Approximately 1800 additional Hellenic Police Officers, together with technical assets were initially deployed in the region. Electronic surveillance and night vision devices were utilised, while patrol boats were deployed in order to strengthen river border controls (Strik 2013, p. 9). New tactics for border surveillance and improved cooperation with the Turkish authorities at the border were employed (Frontex 2013, p. 23). As per June 2013, the operation, the expenses of which were covered by the External Borders Fund, was ongoing with manpower of 735 police officers. This operation at the Greek-Turkish land border was topped up with the building of a barbed wire fence at the 12.5-km-land border in December 2012. The barrier was built without EU funding and cost approximately 3 million Euros (Strik 2013, p. 10).

In early August 2012, operation "Xenios Zeus" was introduced in Athens and then in other urban centres in Greece. Its aim was to crack down on irregular migrants by detecting irregular residents across the country and subsequently deporting them. In the first week of the operation, around 4500 Hellenic Police Officers conducted raids on streets and in run-down apartment blocks, which rendered the sweep as one of the largest ever in the country (Kitsantonis 2012). 
In March 2012, the Greek government announced its 2-year plan to build 30 new detention centres across Greece with a capacity of 10,000 people, financed by the EU. Expansion works also started in the five pre-removal detention centres that currently existed (Strik 2013, p. 10). However, the Government did not proceed with the plan, as it encountered strong resistance from local communities (Strik 2013, p. 10). Then, in August 2012, within the context of the operation "Xenios Zeus" the Minister for Citizen Protection, Nikos Dendias, announced his plans for the creation of 10 operational detention facilities able to host 12,000 people (lefimerida 2012).

Finally, in October 2012 the Government introduced an amendment to the relevant legislation that regulated the administrative detention of irregular migrants and asylum seekers. This amendment extended migrants' and asylum seekers' detention by up to 12 months. Additionally, the Government reduced the period for which irregular migrants have to leave Greece, if not held in detention, from 30 to 7 days.

However, since August 2012, "[r]eports of illegal push-backs [ ... ] ha[d] increased" (Pro Asyl 2013, p. 4, see also Amnesty International 2013a) at the Greek-Turkish borders. At the sea borders, the Hellenic Coast Guard were deploying what is known as "a wall of boats" three large boats and one fast boat. ${ }^{6}$ When a vessel carrying migrants was located, the large boats were aligned at the borderline, and on full throttle they diverted and withheld the vessel, until its captain decided to go back or the vessel was captured by the Turkish authorities. ${ }^{7}$ The fast boat was deployed in case of a pursuit. At the land border, whenever a group of migrants was located in the Turkish territory, Greek officers were arriving at the borderline and were creating a "human wall". ${ }^{8}$ With shouts, gestures and flashlights they were trying to deter the migrants before they crossed the border. ${ }^{9}$ These practices constitute violations of the principle of non-refoulement (Pro Asyl 2013).

Human Rights Watch (HRW) recently released a report on the effects of the operation "Xenios Zeus", where it listed practices that amounted to "arbitrary and discriminatory deprivation of liberty" (2013, p. 2). It has argued that identity checks were based on a clearly discriminatory basis as specific people were systematically targeted depending on their physical characteristics, ethnic and racial profile in the absence of objective criteria, which rendered these practices illiberal (HRW 2013, pp. 3, 5). Additionally, the organisation has suggested that body pat-downs, bag searches, disrespectful treatment, rude, insulting and threatening behaviour, were a routine during these checks, while there were also reports that physical violence had been used in some cases (HRW 2013, p. 4). The report has stated that these practices "violate[d] Greek laws and policies on non-discrimination, justifiable body and bag searches, and grounds for deprivation of liberty" (HRW 2013, p. 5).

During "sweep operations", the Hellenic Police apprehended and detained irregular migrants and asylum seekers who were suspected of carrying infectious diseases, such as HIV, based on their country of origin, poor living conditions, occupation as sex workers, or their drug use (Amnesty International 2012). Another practice involved the apprehension of irregular migrants and asylum seekers in the centre of Athens, and their transportation to the Attica Aliens' Police Directorate, where they had their fingerprints identified (Proto Thema 2013). Afterwards, they were transferred together with drug users and sex workers outside Athens, where they were released (Proto Thema 2013). This practice aimed to discourage the transferees from returning to their old haunts (Proto Thema 2013). Amnesty International (2013b) has condemned these 
practices and has suggested that the disproportionate targeting of vulnerable groups only further marginalized them and exposed them to additional human rights violations.

Migrants and asylum seekers were deprived of their basic human rights in detention, as there was no legal aid, no information and no interpretation (Pro Asyl 2012, p. 3). Detention practices and conditions were described "as amounting to inhuman and degrading treatment" (CPT 2012, p. 12), particularly in the Evros region. According to Pro Asyl $(2012$, p. 3), "detention in Evros [was] synonymous with brutality, despair and dehumanisation". All newly apprehended migrants were automatically detained, without any caseby-case assessment (Pro Asyl 2012, p. 3). Amnesty International (2012) has condemned these practices and has suggested that "[i]mmigration-related detention is used only as a last resort, and arresting irregular migrants without seeking any alternative measures violates Greece's international obligations". Additionally, there were many cases of police violence against detainees, consisting mainly of punches and kicks to the head and body, while there was virtually no complaint mechanism, which resulted in the lack of protection of the victims and impunity for the perpetrators (CPT 2012, p. 12, Pro Asyl 2012, p. 4).

All in all, prior to the May 2012 parliamentary elections in Greece, the largest episode of (in)securitization of migration started to gradually unfold. It involved the routinization of both (in)security and illiberal practices of Greek (in)security professionals, which justifies the (in)securitization theory's assumption that the liberal government of immigration is based not only on liberal, but also on illiberal practices that are engrained within it. The following sections attempt to explain how this routinization of (in)securitization of migration and exceptionalism can be understood as field effects of the very operation of the field of (in)security. However, first, this paper attempts to identify the various risk factors that infuse (in)securitization and exceptionalism within the "governmentality of everydayness".

\section{The "others": notions of risk in the Greek field of (in)security}

Contemporary risk management is based on the notion of imminent danger, which is part of the logic of worst-case scenarios. In contemporary risk management, "any action is better than no action at all" in order to reduce the probability of harm, damage, or danger. Yet, this "preventive dimension" embedded in contemporary risk management generates suspicion and discretion, which end up to (in)securitization processes, and to the reliance on illiberal practices in order to sooth fear and unease. Hence, (in)securitization and exceptionalism become routinized, or else, part of the "governmentality of everydayness", in the way that it happened in Greece in 2012. Suspicion, discretion, fear, and unease, which are natural by-products of contemporary risk management, encompass the risk factors, or else, the objects, of (in)securitization and exceptionalism, that is the very objects that are perceived to create fear, unease, and suspicion to (in)security professionals in the first place. In other words, suspicion, fear, discretion and unease tend to construct risk factors, or else, "Others", who fuel the (in)securitization of migration and exceptionalism, creating a vicious circle of fear and unease. The analysis of Greek (in)security professionals' interviews and masters' dissertations revealed a number of "Others", who stand in stark contrast to security factors, that is Greek (in)security professionals. More specifically, risk factors comprise the immigrants and asylum seekers, Turkey, the EU, and Frontex. 
As far as the "Others" are concerned, all interviewees referred to immigrants and asylum seekers as "illegal immigrants" (lathrometanastes in Greek), a term that fails to capture the important distinction between regular/irregular immigrants, asylum seekers and refugees. The specific choice of this term derives from a certain logic, according to which "in Greece, we don't have immigrants; we only have illegal immigrants" (Kokkinis 2009, p. 127). Moreover, in its heart this frame sees immigrants in Greece as inferior people of lower quality and culture. Kokkinis $(2009$, pp. 96,115$)$ considers immigrants as "pathetic individuals" and "the contemporary version of the barbaric tribes". Barla et al. (2004, p. 65) refer to them as "uncivilised Third Worlders". One of the interviewed police officers was explicit during the formal interview and used degrading terms such as "stinkers" and "animals" to portray immigrants. ${ }^{10}$ Finally, some of the masters' dissertations employ heavily loaded terms to describe the phenomenon of migration. Manos (2011, p. 39), for instance, talks about the "whirlwind of illegal migration", while others use war-like metaphors such as "migrant invasion", "[Greece became] the target of migrants" (Kokkinis 2009, p. 98), and "the armies of miserable migrants" (Barla et al. 2004, p. 64). All in all, it can be argued that the notion of risk relegates the "Others" to the category of cultural and even racial infrahumanity, which facilitates the (in)securitization of immigration and the legitimisation of illiberal practices in immigration management and control.

Furthermore, Turkey is generally viewed with suspicion by Greek (in)security professionals, some of whom argued that the problem of irregular immigration starts with the fact that "[w]e [i.e. Greeks] have a neighbouring country [i.e. Turkey], with which we have national sovereignty problems and which also is a Muslim country". ${ }^{11}$ In this respect, some (in)security professionals argued that Turkey has important national interests in using irregular immigration to Europe and Greece for its own benefit. Tsironis et al. $(2009$, p. 1) argue that Turkey is using migrant smuggling as a means to promote its unsubstantiated claims in the Aegean Sea through the conduct of search and rescue operations in Greek territorial waters. Manos (2011, p. 40) suggests that migrant smuggling brings great economic benefits to Turkey and argues that the Turkish state foments illegal smuggling networks in its territory. Finally, Greek (in)security professionals also believe that Turkey is using immigration "as a weapon to destabilise Greece", ${ }^{12}$ as immigrants tend to "create terrible social problems, problems in the healthcare system etc."13

The EU and Frontex are also treated with suspicion by Greek (in)security professionals with respect to the issues of immigration management and control. More specifically, some (in)security professionals reveal their concerns and disappointment with specific EU policies such as the family reunification directive ${ }^{14}$ and the Dublin II regulation. ${ }^{15}$ Tsironis et al. (2009, p. E4) argue that the application of the family reunification directive means that an additional three to four million migrants will come to Greece, and for this reason "the Greek government must abolish the family reunification measure" (Drymousis 2012, p. 47). Furthermore, Manos (2011, p. 37) argues that the Dublin II regulation constitutes "a huge problem for Greece" as it obliges the country to keep all undocumented migrants that cross its borders.

In the same manner, some (in)security professionals share a negative evaluation of the role of Frontex in Greece, which is perceived as a force that has been deployed in Greece in order to serve the interests of Central and Western European states. There is a common belief that Frontex has minimum to no contribution to the reduction of irregular migration flows. In this respect, one of the interviewees suggested that Frontex is doing "nothing at 
all" about irregular migrants, as "[... ] from the moment somebody enters your country illegally $[. .$. ] you can't send him back where he came from, since refoulement is not permitted". ${ }^{16}$ The same interviewee argued that "what Frontex does is to record these people and let them go. This is the two-faced Europe". ${ }^{17}$ Another interviewee stated that Frontex officers have been deployed in Greece in order to record all foreigners that enter the country, for when irregular migrants registered in Greece get arrested in Germany, for instance, then Greece is obliged to accept them back according to the Dublin II regulation. ${ }^{18}$ In this regard, "[i]t's in their [i.e. Frontex's] interests to record foreigners, because they are incapable of deterring them". ${ }^{19}$ All in all, the stance of the EU is largely perceived as hypocritical. (In)security professionals express their disappointment with the lack of solidarity and the unequal responsibility-sharing among EU member states regarding the management of undocumented immigrants: "if the EU really wanted to support Greece, then the burden of illegal immigrants would be shared among all member states. There is hypocrisy on behalf of the EU". ${ }^{20}$

Greek (in)security professionals' framing of the "Others" through the prism of risk constitutes the basis of understanding the field of (in)security as a field of forces, struggles, and domination. This framing, which is guided by contemporary risk management and the feelings of suspicion, discretion, fear, and unease that it creates, underpins the structural struggles that occur within the field of (in)security, which are inherent in the very operation of the field of (in)security. In turn, these struggles generate the processes of (in)securitization and exceptionalism, which are field effect of the very operation of the field of (in)security. To put it differently, it is the structural competition between actors with different forms of capital, legitimacy, and interests, and their ability to protect the field of (in)security and dominate it over the definition of security, which produces the phenomena of (in)securitization and exceptionalism. The following sections attempt to explain how (in)securitization and exceptionalism can be understood as field effects of the very operation of the field of (in)security.

\section{The field of (in)security}

This section analyses the Greek field of (in)security as part of the broader European field of (in)security. More specifically, the first and second parts analyse the fields of (in)security along the dimensions of forces and struggles, and explore the positions of Greek (in) security professionals vis-à-vis those of their European counterparts within these fields. The third part focuses on the Greek field of (in)security, which is analysed along the dimension of domination. This section shows that the European field of (in)security is a solid structure that attracts its agents from different national (in)security fields towards each other through strong centripetal forces. Yet, the commonalities that keep the agents of different national (in)security fields close to one another, render the European field of (in)security ostensibly homogeneous. Strong centrifugal forces that manifest themselves as struggles and competitions for domination between different agents of the fields disperse individuals towards other stakes. The effects of these struggles and competitions are translated into routinized processes of (in)securitization and exceptionalism, as (in)security professionals strive to cope with the vicious circle of fear and unease that they create, safeguard their interests, and preserve their sense of the game. 


\section{The field of (in)security as a field of forces}

The field of (in)security is characterised by a set of common beliefs, practices, and technologies (Bigo et al. 2010a, p. 51). It functions as a field of forces exercising centripetal relational forces on the agents engaged in it based on a specific homogeneity found in these agents' bureaucratic interests, their similar ways of defining potential risks and threats and of collecting data and information on these risks through diverse technologies and routines (Bigo 2006b, p. 23). Thus, the field of (in)security professionals functions "through the discourses of cooperation, the interests of some agents for specific techniques of investigation and other issues connected with their institutional position, their personal trajectory and their social and symbolic capital" (Bigo et al. 2010a, p. 14).

Agents of the European field of (in)security share a "doxa", a "common sense" of what is at stake regarding security at the European level, which does not preclude disagreements, yet it implies that there is always agreement on what and how one disagrees (Bigo et al. 2010b, p. 53). This "doxa" consists of the secondary importance that these professionals attribute to the borders as the main "line of defence" against threats (Bigo et al.2010b, p. 53). Emphasis is put on the external action of internal security agencies and the policing of both internal and external borders of the EU, which entails the employment of proactive/preventive measures before a threat manages to cross the borders (Bigo et al. 2010b, p. 53). Second, this "doxa" also comprises the focus on global, transnational or "regional" security, which emphasises "policing at a distance" and the extensive use of databases (Bigo et al. 2010b, p. 53). Third, the (over)valuation of information technologies, digitalisation, and collection of data that aim at the proactive identification and localisation of risk before its materialization is a central element of this "doxa". Finally, there is a shared agreement on the centrality of the question of the relevant priorities regarding threats (Bigo et al. 2010b, p. 53).

The same centripetal relational forces are exercised on Greek (in)security professionals too, rendering them part of the European field of (in)security. Greek (in)security professionals' regional/international security considerations revolve around the definition of security as cultural security. Kokkinis (2009, p. 150) argues that Islam penetrates the West, exports Islamic faith and becomes dominant and imperialistic right in the heart of Europe. Islam is "impossible to be assimilated by the Western civilisation", as it is a "foreign body" (Kokkinis 2009, p. 150). Yet, "Muslims in Europe are behaving as if they are living in a predominantly Muslim society" (Drymousis 2012, p. 43), while "the vast majority considers themselves as bearers of a superior civilisation" and "despise the European lifestyle and conspire to take it over" (Kokkinis 2009, p. 146). In turn, this "threatens with extinction the established rights of the peoples of Europe" (Drymousis 2012, p. 30).

Moreover, Greek (in)security professionals share the same anxiety about incalculable risks with their European counterparts: "since you don't know his [i.e. the immigrant's] personal details, he can be anything!". ${ }^{21}$ This inability to know a person's past and present carries with it the powerlessness to predict his/her future behaviour, which informs the logic of worst-case scenarios that is embedded in contemporary governmentality of fear and unease: "we don't know what these people [i.e. the migrants] are. We don't know if they are dangerous. We don't know their past!". ${ }^{22}$ However, this common anxiety about incalculable risks does not preclude disagreements on who or what these incalculable risks are, since the definition of risk factors is open to interpretation, as was described in a previous section. 
Thus, emphasis is placed on the technologization of risk management, the collection of personal data and information regarding migrants that aims in their proactive/preventive control before they materialize themselves as threats: "there is no way in stopping somebody from entering Greece. Deterrence is impossible. The only thing that we are doing here is to record them". ${ }^{23}$ By extension, this reflects the non-importance that Greek (in) security professionals attribute to borders as the main "line of defence" against the immigration threat: "the control and deterrence of illegal migration is futile" 24 and "[t]he deterrence of smuggling boats [... ] does not produce substantial results" (Tsironis et al. 2009, p. H2). In the same manner, another interviewee suggested that "patrols do not contribute anything to the control of illegal migration at the moment". ${ }^{25}$

Additionally, Greek (in)security professionals are also attracted to their European counterparts through the centripetal forces of interagency cooperation and externalisation of border controls. Regarding the former, an interviewee argued that "the arrival of Frontex made us more flexible, as we were able to split the patrol zones between us". ${ }^{26}$ Another interviewee addressed the importance of the exchange of know-how between Greek and foreign agents through their cooperation and the key role of databases in this regard:

Frontex officers [ ... ] are inspecting vehicles that enter Greece much faster and equally efficiently with us. [...] They cross-check the vehicles' number plates with the data in their national databases, in which only themselves have direct access. This is something that would normally take us a whole day without them. ${ }^{27}$

Regarding the externalisation of border controls, an interviewee highlighted the important role of Turkish authorities in the proactive control of irregular migrants: "[a]s a matter of fact, patrols can be an effective deterrence measure only when they are deployed on both sides of the border". ${ }^{28}$ The same interviewee also stressed the key role of thermal and night vision goggles and cameras in the preventive location of would-be irregular migrants in the Turkish territory. ${ }^{29}$ This technologization of border controls allows Greek agents to instantly contact their Turkish counterparts in order to act proactively before the risk materialises itself in the Greek territory. In this regard, Frontex helicopters also assist in the externalisation of border controls as they locate would-be irregular migrants in the Turkish territory and inform the Greek and Turkish authorities in order to act accordingly. ${ }^{30}$

All in all, on the surface, (in)security professionals share a focus on various aspects of European security: the governmentality of fear and unease through the logic of worstcase scenarios and incalculable risks; the discourses of the secondary importance of borders as the "main line of defence" against risks; the employment of proactive/preventive measures through the emphasis on "policing at a distance" and the extensive use of databases; the externalisation of border controls; and interagency/intergovernmental cooperation. However, despite these commonalities that render the European field of (in)security seemingly homogeneous, there is significant competition between (in)security professionals over the definition of security and the appropriate control and management of migration. These power struggles occur due to the limited results that these centripetal field forces produce in the control/management of irregular immigration. In simple terms, the aforementioned discourses fail to preserve Greek (in)security professionals' "sense of the game", which jeopardises their interests. In other words, these discourses fail to 
pretend that they are doing something that they cannot actually do: controlling the numbers of irregular migrants in Greece. In this respect, and in order to safeguard their role as guarantors of security in the country, Greek (in)security professionals enter into power struggles with their colleagues over the definition of security, risk factors, and the ways to deal with them, generating in this way processes of (in)securitization and exceptionalism.

\section{The field of (in)security as a field of struggles}

Despite these commonalities, the field of (in)security is not homogeneous, as competition within and between actors persists about the boundaries and definition of the term "security", the pertinent knowledge concerning threats, risks, vulnerabilities, or even opportunities, and the prioritization of different threats (Bigo 2006b, p. 24). Nevertheless, this heterogeneity exists because in fact these actors share the same interests, the same sense of the game and the same perception of the "stakes that are at stake" (Bigo 2006 b, p. 24). Greek (in)security professionals, as well as their European counterparts, compete with each other over the "stakes that are at stake", or else, the definition of security and the appropriate ways to deal with risk factors, in order to safeguard their role as guarantors of security (interests), by pretending to do what they cannot actually do: controlling the numbers of irregular migrants (sense of the game).

The Europeanisation of immigration policy has altered the nature of national fields (Leander 2009, p. 14). Progress has been achieved in the Europeanisation of security cooperation, yet, a similar integration in the field of justice and liberty is absent (Bigo et al. 2010b, pp. 51, 52). However, the integration in security matters does not imply harmonisation, as the European field of (in)security is structured around multiple meanings, cleavages, oppositions and lines of confrontation (Bigo et al. 2010b, p. 54). Some actors still "insist on traditional solutions and rely on local knowledge and a national security agenda in order to cope with danger" (Bigo et al. 2009, p. 291). The old game of national security and sovereign states is still on and hinders practices of collaboration (Bigo et al. 2009 , p. 292). National interests and traditional military thinking struggle to cope with the logic of "policing at a distance", the discourse about the essentiality of collaboration, and new technological trends (Bigo et al. 2009, p. 292). For these actors only human and local sources and specific inquiries are capable of producing clear knowledge (Bigo et al. 2009, p. 292).

Greek (in)security professionals are particularly insistent on a national security agenda. Their focus on national interests and traditional military thinking informs a narrow definition of security as an all-inclusive conception of national security. Security has to do with "the protection of the existence and operation of the State's institutions through the safeguarding and strengthening of its various aspects of power, that is the economic, demographic, political, cultural and defensive" (Kokkinis 2009, p. 10). In this respect, security "is influenced by and related to the Armed Forces. [... ] There is no national security without strong Armed Forces" (Barla et al. 2004, p. 57). Mass migration then, is, first and foremost, a national security issue (Manos 2011, p. 49). This thinking informs the use of the aforementioned war-like metaphors in relation to immigrants in Greece.

The identification of security with national security impedes practices of collaboration and obstructs any prospects of externalisation of border controls by instilling fear and 
suspicion into Greek-Turkish relations, taking into account the traditionally turbulent Greek-Turkish relations and the fact that almost all irregular border-crossings take place at the Greek-Turkish borders. This rationale places Turkey among risk factors, or else, the "Others", and legitimises the idea that Turkey is using irregular immigration to Europe and Greece in order to serve its own national interests.

Additionally, the old game of national security and sovereign states also hinders intergovernmental collaboration, that is the collaboration between Greece and other EU member states with respect to the management and control of irregular immigrants and asylum seekers. In this respect, specific European immigration policies, such the Dublin II regulation and the family reunification directive, are viewed with suspicion and disbelief by Greek (in)security professionals, since they are interpreted as security mechanisms that aim to protect the national interests of the prosperous EU member states over the interests of the states at the fringes of the EU.

Furthermore, this opposition to the Europeanisation of immigration policies is accompanied by the resistance to "policing at a distance" and the technologization of risk management that hinders interagency cooperation, or else, the cooperation between Greek (in)security professionals and their Frontex counterparts. More specifically, Frontex tends to be understood as the extended arm of Western and Central EU member states at the external borders of the EU, which safeguards the national interests of the core, rather than the periphery of the Union.

By extension, these struggles lead Greek (in)security professionals to favour instead the use of human and local sources in the management of borders as a last resort, in order to safeguard their interests and restore their sense of the game. This choice opens the door to processes of (in)securitization and exceptionalism. In this regard, one of the interviewees stated that "in the beginning, the EU supported the idea of building and funding the fence in Evros. But later on, they changed their minds. Such a great hypocrisy!". ${ }^{11}$ Another interviewee suggested that "we must make Greece inhospitable to migrants. I mean that all Greeks must stop our financial relations with them in order to make them understand that there is nothing here and leave. No charity, no philanthropy, no job offers!". ${ }^{32}$ Finally, a third interviewee put forward the measure of detention as the ideal immigration control practice: "in the beginning we were considering detention as a deterrence mechanism to illegal immigration and we tried to detain them for as long as possible". ${ }^{33}$ Indeed, in the logic of risk and worst-case scenarios "any action is better than no action at all" (Bigo and Guittet 2011, p. 492). This ends up unsettling the balance between security and liberty by "always favouring security in its most coercive modes" (Bigo and Guittet 2011, p. 492).

All in all, the analysis of the positions of Greek (in)security professionals in the European field of (in)security uncovers significant struggles between Greek (in)security professionals and their European counterparts, which partly explain processes of (in)securitization and exceptionalism at the fringes of the EU. Greek (in)security professionals still insist on traditional military thinking and national interests, and rely on local knowledge, human sources and a national security agenda in order to cope with risk factors, safeguard their role as guarantors of national security, and preserve their sense of the game. In other words, they embrace a "Cold War" logic in defining security and dealing with risk factors. In contrast, European (in)security professionals, appear to promote a much broader European security agenda, the externalisation of border controls, intergovernmental/interagency cooperation, and the increased utilisation of new technological 
trends in the control and management of irregular migration. These struggles between Greek and European (in)security professionals translate into heterogeneous positions within the field of (in)security: the essentiality of collaboration against national interests; traditional military thinking in opposition to "policing at a distance"; national in contrast to European security agendas; and human/local sources contra new technological trends.

\section{The field of (in)security as a field of domination}

The field of (in)security is also a field comprised of unequal positions. It functions as a field of domination in relation to other social fields, such as the field of politics professionals, and excludes other actors, such as NGOs, from crossing its boundaries by disqualifying their viewpoints (Bigo 2006b, pp. 26, 27). Thus, the field of (in)security tends to monopolise the power to define "legitimately recognised threats" and enters into struggles for the authority to impose its definition of who and what constitutes risk and to settle a specific set of practices to deal with it (Bigo 2006b, pp. 26, 27). The field of (in)security exercises its centripetal relational force on its own actors by its power to impose its definition of risk on other actors "through the belief that the insiders of the field possess, as 'experts', the supplementary knowledge and secrets that only professionals may have" (Bigo 2006b, pp. 26, 27).

With specific regard to the Greek field of (in)security then, Greek (in)security professionals compete with politics professionals and NGOs over the definition of security and the ways to deal with risk factors, in order to safeguard their role as guarantors of security, and preserve their sense of the game. This competition, however, gives way to (in)securitization processes and exceptionalism. Reactionary practices and rationales with respect to the risk management of immigration become routinized, as Greek (in) security professionals "harden" the boundaries of the field of (in)security, in order to prevent politics professionals and NGOs from crossing them, safeguard their interests and preserve their sense of the game.

Greek (in)security professionals are involved in a struggle for domination with the field of politics professionals over what constitutes risk, and the settlement of the appropriate measures to deal with it. With regard to the former, Greek (in)security professionals suggest that "nowadays, migration and illegal migration constitute a single phenomenon" (Kokkinis 2009, p. 14). In turn, this entails that multiculturalism is identified as a risk factor too: "it would be a great fallacy for the Greek people to be deceived by these nice words about humanitarianism, universalism, and 'Multiculturalism', and fall for the destruction of their national identity" (Tsironis et al. 2009, p. E4). Indeed,

the political, social and spiritual elites of the country seem to have utterly and unquestionably accepted [ ... ] the 'multicultural' experiments that pose a direct threat to the ethnic and social coherence, national security, and political and state stability of the country. (Kokkinis 2009, p. 119)

Regarding the settlement of the appropriate policies and practices to deal with risk, Greek (in)security professionals find the national migration legislation as "largely pro-migrant" that "functions as a magnet to illegal immigrants": ${ }^{34}$

[t]he last 20 years, Greek governments have taken up a liberal, humanitarian and progressive role in dealing with illegal immigration. Thus, our country's immigration policies are 
characterised by a weird tolerance, which constitutes a pull-factor for waves of illegal immigrants. (Manos 2011, p. 33)

Moreover, "mass regularisations actually rewarded immigrants who entered the country illegally $[\ldots]$ and gave incentive to others to enter the country illegally too" (Tsironis et al. 2009, p. E8). Additionally, (in)security professionals challenge the politics professionals' suggested change in the nationality law that would introduce elements of jus soli. This change is interpreted as a potential risk and "the pinnacle of the malaise, weakness, and suspicious indifference of our political system towards the immigration problem" (Manos 2011, pp. 39, 40).

Greek (in)security professionals also maintain that "there is no willingness on behalf of our Ministry [i.e. the Ministry of Public Order and Citizen Protection] to crack down on illegal residence in the centre of Athens". ${ }^{35}$ Another interviewee argued that "'sweep operations' are just a smokescreen. They are part of political parties' political calculations". ${ }^{36}$ Finally, Greek (in)security professionals criticise the inefficiency of labour market controls and identify specific political calculations behind it:

if we take substantial measures that exclude migrants from the labour market, then the production in some sectors of the economy, such as the agriculture, will drop, since natives do not want to work there. Thus, the "ineffectiveness" of labour market controls might suggest the willingness of authorities to let immigrants work, where Greeks refuse to work. (Tsironis et al. 2009, p. E1)

Furthermore, Greek (in)security professionals are in a constant struggle for domination with NGOs that attempt to cross the boundaries of the field of (in)security. They defend their monopoly to legitimately identifying and dealing with threats by discrediting the NGOs' views on the "stakes that are at stake" through the emphasis on their status as "experts". In this respect, Drymousis (2012, p. 34) suggests that NGOs "are pushing for the admission of mass illegal immigration, adopting a discourse of universal human rights, usually ignoring the fact that the source of power internationally is always the nation-state". An interviewee argued that NGOs "deal with human rights, while we [i.e. the Hellenic Coast Guard] deal with border guarding. We respect human rights, but we are not interested in them. NGOs contribute nothing" ${ }^{37}$ In the same manner, another interviewee stated that "NGOs just make our jobs harder". 38 Along the same lines, another interviewee suggested that "the NGOs' job is not hard. Hard is breaking a door and entering a house, without knowing whether somebody is holding a gun behind your back. Talking to a bunch of stinkers is not hard!". ${ }^{39}$

More often than not, these struggles lead to the exclusion of NGOs from entering the field of (in)security. One of the interviewees argued that "I don't like it when they [i.e. the NGOs] cross the lines. [... ] I never carry my opinions and ideas with me at work; I leave them back home." ${ }^{40}$ Accordingly, another interviewee added that "we have come closer with the NGOs in recent years. However, does the wolf love the sheep? Our relations may have improved, but the wolf never loves the sheep". ${ }^{41}$

All in all, the structural competitions within the field of (in)security that produce processes of (in)securitization and exceptionalism, also materialise themselves as struggles for domination between Greek (in)security professionals and politics professionals over the authority to define who/what constitutes risk and how to deal with it. Moreover, the structural competitions within the field of (in)security also translate into struggles 
for domination between Greek (in)security professionals and NGOs for the exclusion of the latter from entering the field of (in)security. What creates the processes of (in)securitization and exceptionalism in this case then, are the power struggles between Greek (in)security professionals, on the one hand, and politics professionals and NGOs, on the other, which occur when the latter actors attempt to penetrate the boundaries of the field of (in)security. This causes the contraction of the boundaries of the field of (in)security, as Greek (in) security professionals routinely try to safeguard their role as guarantors of security and preserve their sense of the game, which translates into (in)securitization processes and exceptionalism.

\section{Conclusion}

This paper has argued that (in)securitization and illiberal practices at the fringe of the EU are engrained in ordinary law and the everyday routine work of (in)security professionals. More specifically, by drawing on the (in)securitization theoretical framework, and by using Greece as a case study, it has demonstrated how (in)securitization and illiberal practices are produced through the construction of risk factors, which underpin the structural competition between different actors of the field of (in)security, with different forms of capital, legitimacy and interests, and their ability to protect their field and dominate it over the definition of security and the appropriate control and management of migration.

Contemporary risk management and the logic of worst-case scenarios generate suspicion, discretion, fear, and unease to (in)security professionals with respect to the control and management of irregular immigration. These feelings encompass the risk factors, or else, the objects of (in)securitization and exceptionalism, and also lead to the construction of convenient "Others", who are perceived as equally responsible for the generation of these feelings. Hence, apart from immigrants and asylum seekers, Turkey, the EU, and Frontex are also constructed as "Others", as the centripetal forces that are exercised on the Greek field of (in)security fail to pretend that they are controlling irregular immigration.

The analysis of the Greek field of (in)security as part of the broader European field revealed a field of forces, where Greek (in)security professionals are attracted to their European counterparts by centripetal forces that include: the focus on European security as cultural security; the governmentality of fear and unease through the logic of worstcase scenarios; the discourses of the secondary importance of borders as the main "line of defence" against risks; the employment of proactive/preventive measures through the emphasis on "policing at a distance" and the extensive use of databases; the externalisation of border controls; and interagency/intergovernmental cooperation.

Yet, despite these commonalities that render the European field of (in)security seemingly homogeneous, strong centrifugal forces are exercised upon its actors. These forces that manifest themselves as competition between Greek and European (in)security professionals produce the field effects of (in)securitization and illiberal practices. This competition materialises itself as struggles between the discourse about the essentiality of collaboration and national interests; traditional military thinking and "policing at a distance"; national security and regional/international security; and human/local sources and new technological trends. Indeed, Greek (in)security professionals still insist on traditional solutions and rely on local knowledge and a national security agenda in order to cope with the risk factors that they themselves construct. Yet, this competition also materialises itself 
as a struggle for domination over the authority to define who/what constitutes risk and how to deal with it between Greek (in)security professionals and politics professionals, and as a struggle for the exclusion of NGOs from entering the field of (in)security.

All in all, (in)securitization of immigration and exceptionalism occur when (in)security professionals at the fringes of the EU feel that their interests, that is their role as guarantors of security, and their sense of the game, that is pretending to control irregular immigration, are jeopardised by the centripetal forces that are exercised on their national fields of (in)security. In this regard, the routinization of (in)securitization and exceptionalism occurs as a means of last resort, since "any action is better than no action at all" according to contemporary risk management. At the fringes of the EU, (in)securitization and exceptionalism constitute (in)security professionals' expedient to safeguard their interests and preserve their sense of the game, when the centripetal forces that are exercised on their national fields fail to pretend that they are controlling irregular immigration.

\section{Disclosure statement}

No potential conflict of interest was reported by the author.

\section{Notes}

1. Also known as the "Paris School" of critical security studies.

2. Recent cases include Nieciecki v. Greece (11677/11, 4 December 2012), Tzamalis and Others v. Greece (15894/09, 4 December 2012), Lin v. Greece (58158/10, 6 November 2012), Ahmade v. Greece (50520/09, 25 September 2012) and Mahmundi and Others v. Greece (14902/10, 31 July 2012).

3. Women were allowed to join the Hellenic Police in 1983 for the first time. However, a $10 \%$ quota was established, which remained in place until 2003. This has led to the overrepresentation of men in the Hellenic Police, which is partly responsible for the gender biased sample. Additionally, women are particularly underrepresented in Police services that deal with irregular immigrants, but not in the Asylum Department.

4. The Greek security professionals that prepared the dissertations were either Police Majors or Police Lieutenant Colonels.

5. This approach is known as the "Copenhagen School" of critical security studies.

6. Hellenic Coast Guard Officer, Sea Borders Protection Directorate, Athens, 19 January 2012.

7. Hellenic Coast Guard Officer, Sea Borders Protection Directorate, Athens, 19 January 2012.

8. Hellenic Police Officer, Hellenic Police Directorate, Orestiada, 6 April 2012.

9. Hellenic Police Officer, Hellenic Police Directorate, Orestiada, 6 April 2012.

10. Hellenic Police Officer, Attica Aliens' Police Directorate, Athens, 18 January 2012.

11. Hellenic Police Officer, Attica Aliens' Police Directorate, Athens, 18 January 2012.

12. Hellenic Police Officer, Attica Aliens' Police Directorate, Athens, 19 January 2012.

13. Hellenic Police Officer, Attica Aliens' Police Directorate, Athens, 19 January 2012.

14. See Council Directive, 2003/86/EC, The Right to Family Reunification.

15. See Council Regulation, 343/2003, Establishing the criteria and mechanisms for determining the Member State responsible for examining an asylum application lodged in one of the Member States by a third-country national.

16. Hellenic Police Officer, Attica Aliens' Police Directorate, Athens, 19 January 2012.

17. Hellenic Police Officer, Attica Aliens' Police Directorate, Athens, 19 January 2012.

18. Hellenic Police Officer, Attica Aliens' Police Directorate, Athens, 19 January 2012.

19. Hellenic Police Officer, Attica Aliens' Police Directorate, Athens, 19 January 2012.

20. Hellenic Police Officer, Attica Aliens' Police Directorate, Athens, 19 January 2012.

21. Hellenic Police Officer, Hellenic Police Directorate, Lesvos, 21 March 2012. 
22. Hellenic Coast Guard Officer, Hellenic Coast Guard, Lesvos, 9 March 2012.

23. Hellenic Police Officer, Hellenic Police Directorate, Lesvos, 9 March 2012.

24. Hellenic Police Officer, Attica Aliens' Police Directorate, Athens, 19 January 2012.

25. Hellenic Police Officer, Hellenic Police Directorate, Orestiada, 6 April 2012.

26. Hellenic Coast Guard Officer, Hellenic Coast Guard, Lesvos, 9 March 2012.

27. Customs Officer, Alexandroupoli Customs, Alexandroupoli, 26 April 2012.

28. Hellenic Police Officer, Hellenic Police Directorate, Alexandroupoli, 18 April 2012.

29. Hellenic Police Officer, Hellenic Police Directorate, Alexandroupoli, 18 April 2012.

30. Hellenic Police Officer, Hellenic Police Directorate, Alexandroupoli, 18 April 2012.

31. Hellenic Police Officer, Hellenic Police Directorate, Orestiada, 6 April 2012.

32. Hellenic Police Officer, Attica Aliens' Police Directorate, Athens, 19 January 2012.

33. Hellenic Police Officer, Hellenic Police Directorate, Lesvos, 9 March 2012.

34. Hellenic Police Officer, Attica Aliens' Police Directorate, Athens, 19 January 2012.

35. Hellenic Police Officer, Attica Aliens' Police Directorate, Athens, 24 January 2012.

36. Hellenic Police Officer, Attica Aliens' Police Directorate, Athens, 19 January 2012.

37. Hellenic Coast Guard Officer, Hellenic Coast Guard, Lesvos, 8 March 2012.

38. Hellenic Police Officer, Attica Aliens' Police Directorate, Athens, 19 January 2012.

39. Hellenic Police Officer, Attica Aliens' Police Directorate, Athens, 18 January 2012.

40. Hellenic Police Officer, Hellenic Police Directorate, Orestiada, 6 April 2012.

41. Hellenic Police Officer, Attica Aliens' Police Directorate, Athens, 18 January 2012.

\section{Notes on contributor}

Dr Dimitris Skleparis is a Postdoctoral Research Fellow at the Hellenic Foundation for European and Foreign Policy (ELIAMEP).

\section{References}

Amnesty International, 2012. Greece plans sweep of migrants and asylum-seekers [online], 2 April. Available from: http://www.amnesty.org/en/news/greece-plans-sweep-migrants-and-asylumseekers-2012-04-02 [Accessed 28 July 2015].

Amnesty International, 2013a. Frontier Europe: human rights abuses on Greece's border with Turkey [online]. Available from: http://www.amnesty.org/en/library/asset/EUR25/008/2013/en/ d93b63ac-6c5d-4d0d-bd9f-ce2774c84ce7/eur250082013en.pdf [Accessed 20 July 2015].

Amnesty International, 2013b. Greece must withdraw the provision on forced HIV testing and end harassment of transgender women [online], 18 July. Available from: http://www.amnesty.ca/news/ public-statements/greece-must-withdraw-the-provision-on-forced-hiv-testing-and-end-harassme nt-o [Accessed 20 July 2015].

Aradau, C., 2008. Forget equality? Security and liberty in the "War on Terror". Alternatives: global, local, political, 33 (3), 293-314.

Aradau, C. and Van Munster, R., 2007. Governing terrorism through risk: taking precautions, (un) knowing the future. European journal of international relations, 13 (1), 89-115.

Aradau, C. and Van Munster, R., 2009. Exceptionalism and the 'War on Terror': criminology meets international relations. British journal of criminology, 49 (5), 686-701.

Aradau, C., Lobo-Guerrero, L., and Van Munster, R., 2008. Security, technologies of risk, and the political: guest editors' introduction. Security dialogue, 39 (2-3), 147-154.

Balzacq, T., 2005. The three faces of securitization: political agency, audience and context. European journal of international relations, 11 (2), 171-201.

Balzacq, T., 2008. The policy tools of securitization: information exchange, EU foreign and interior policies. Journal of common market studies, 46 (1), 75-100.

Balzacq, T., et al., 2010. 'Security practices'. International studies encyclopedia online. Denmark: R.A. Blackwell Publishing, Blackwell reference online. 18 March. Available from: http://www. isacompendium.com/subscriber/tocnode?id=g9781444336597_chunk_g978144433659718_ss12 [Accessed 28 May 2015]. 
Barla, S., et al., 2004. Consequences of the demographic problem and illegal migration in national security: threat or opportunity? Dissertation (MA). School of National Security, Greece.

Basaran, T., 2008. Security, law, borders: spaces of exclusion. International political sociology, 2 (4), 339-354.

Bigo, D., 2002. Security and immigration: toward a critique of the governmentality of unease. Alternatives: global, local, political, 27 (1), 63-92.

Bigo, D., 2006a. Security, exception, ban and surveillance. In: D. Lyon, ed. Theorizing surveillance, the panopticon and beyond. Devon, UK: Willan, 46-68.

Bigo, D., 2006b. Globalized (in)security: the field and the ban-opticon. In: D. Bigo and A. Tsoukala, eds. Illiberal practices of liberal regimes: the (in)security games. Paris: Editions L'Harmattan, 5-49.

Bigo, D., 2008a. Globalized (in)security: the field and the ban-opticon. In: D. Bigo and A. Tsoukala, eds. Terror, insecurity and liberty: illiberal practices of liberal regimes after 9/11. London: Routledge, $10-48$.

Bigo, D., 2008b. International political sociology. In: P. Williams, ed. Security studies: an introduction. London: Routledge, 116-129.

Bigo, D., 2011. Pierre Bourdieu and international relations: power of practices, practices of power. International political sociology, 5 (3), 225-258.

Bigo, D., 2012. Security, surveillance and democracy. In: D. Lyon, K.D. Haggerty, and K. Ball, eds. Routledge handbook of surveillance studies. Abingdon, UK: Routledge, 277-284.

Bigo, D. and Guild, E., 2005. Controlling frontiers: free movement into and within Europe. Aldershot: Ashgate.

Bigo, D. and Guittet, E.-P., 2011. Northern Ireland as metaphor: exception, suspicion and radicalization in the 'War on Terror'. Security dialogue, 42 (6), 483-498.

Bigo, D. and Tsoukala, A., 2008. Understanding (in)security. In: D. Bigo and A. Tsoukala, eds. Terror, insecurity and liberty: illiberal practices of liberal regimes after 9/11. London: Routledge, 1-9.

Bigo, D., Bonditti, P., and Olsson, C., 2010a. Mapping the European field of security professionals. In: D. Bigo, S. Carrera, E. Guild, and R.B.J. Walker, eds. Europe's 21st century challenge: delivering liberty. Farnham, UK: Ashgate, 49-63.

Bigo, D., Guild, E., and Walker, R.B.J., 2010b. The changing landscape of European liberty and security. In: D. Bigo, et al., eds. Europe's 21st century challenge: delivering liberty. Farnham, UK: Ashgate, 1-29.

Bigo, D., et al., 2009. The changing landscape of European liberty and security: the mid-term report of the CHALLENGE project. International social science journal, 59 (192), 283-308.

Bonditti, P., 2004. From territorial space to networks: a Foucaldian approach to the implementation of biometry. Alternatives, 29 (4), 465-482.

Bourdieu, P., 1998. Practical reason: on the theory of action. Cambridge: Polity Press.

Buzan, B., Waever, O., and De Wilde, J., 1998. Security: a new framework for analysis. Boulder, CO: Lynne Rienner.

CPT, 2012. Report to the Government of Greece on the visit to Greece carried out by the European Committee for the Prevention of Torture and Inhuman or Degrading Treatment or Punishment (CPT) from 19 to 27 January 2011 [online], 10 January, Available from: http://www.cpt.coe.int/ documents/grc/2012-01-inf-eng.pdf [Accessed 28 May 2015].

Donkin, S., 2014. Preventing terrorism and controlling risk: A comparative analysis of control orders in the UK and Australia. New York: Springer.

Drymousis, I., 2012. The Muslim economic migrants in Greece and the relevant Greek political approach (weaknesses, problems and national planning within the context of the European reality and the Middle Eastern systemic instability). Dissertation (MA). Hellenic National Defence College, Greece.

Frontex, 2013. Annual risk analysis 2013 [online]. Available from: http://www.frontex.europa.eu/ assets/Publications/Risk_Analysis/Annual_Risk_Analysis_2013.pdf [Accessed 28 May 2015].

Guild, E., Groenendijk, C.A., and Carrera, S., 2009. Illiberal liberal states: immigration, citizenship, and integration in the EU. Aldershot: Ashgate.

HRW, 2013. Unwelcome guests: Greek Police abuses of migrants in Athens [online], 12 June. Available from: http://www.refworld.org/docid/51bae3274.html [Accessed 28 May 2013].

Huysmans, J., 2004. Minding exceptions: the politics of insecurity and liberal democracy. Contemporary political theory, 3 (3), 321-341. 
Huysmans, J., 2006. The politics of insecurity: fear, migration, and asylum in the EU. Abingdon, UK: Routledge.

Huysmans, J. and Buonfino, A., 2008. Politics of exception and unease: immigration, asylum and terrorism in parliamentary debates in the UK. Political studies, 56 (4), 766-788.

lefimerida, 2012. Ten new detention centres for illegal migrants [online], 19 August. (In Greek).

Jabri, V., 2006. War, security and the liberal state. Security dialogue, 37 (1), 47-64.

Jenkins, R., 1992. Pierre Bourdieu. London: Routledge.

Karyotis, G., 2012. Securitization of migration in Greece: process, motives, and implications. International political sociology, 6 (4), 390-408.

Karyotis, G. and Patrikios, S., 2010. Religion, securitization and anti-immigration attitudes: the case of Greece. Journal of peace research, 47 (1), 43-57.

Karyotis, G. and Skleparis, D., 2013. Qui bono? The winners and losers of securitising migration. Griffith Law Review, 22 (3), 683-706.

Karyotis, G. and Skleparis, D., 2014. Migrant mobilisation during the economic crisis: identity formation and dilemmas. In: M. Tsilimpounidi, and A. Walsh, eds. Remapping 'Crisis': a guide to Athens. Ropley, Hampshire: Zero Books, 124-143.

Kitsantonis, N., 2012. As Greece rounds up migrants, official says 'invasion' imperils national stability. The New York Times [online], 6 August, Available from: http://www.nytimes.com/2012/08/07/ world/europe/vast-police-operation-targets-migrants-in-athens.html?_r=2\& [Accessed 28 May 2015].

Kokkinis, N., 2009. National security and migration policy. Dissertation (MA). School of National Security, Greece.

Leander, A., 2009. Habitus and field. Department of Intercultural Communication and Management, Copenhagen Business School, Working Paper No. 9.

Lippert, R.K. and Williams, J.W., 2012. Taking exception: the cases of financial and urban governance. Social \& legal studies, 21 (1), 51-72.

Manos, D., 2011. Muslim economic migrants in Greece and the relevant Greek policy: approach, weaknesses, problems, and national planning within the context of the European reality and the Middle Eastern instability. Dissertation (MA). Hellenic National Defence College, Greece.

Mythen, G. and Walklate, S., 2006. Criminology and terrorism: which thesis? Risk society or governmentality? British journal of criminology, 46 (3), 379-398.

Pro Asyl, 2012. Walls of shame: accounts from the inside [online]. 10 April. Available from: http:// www.proasyl.de/fileadmin/fm-dam/q_PUBLIKATIONEN/2012/Evros-Bericht_12_04_10_BHP.pdf [Accessed 28 May 2015].

Pro Asyl, 2013. Pushed back: systematic human rights violations against refugees in the Aegean Sea and at the Greek-Turkish land border [online]. Available from: http://tinyurl.com/og2lkyd [Accessed 28 May 2015].

Proto Thema, 2013. They arrest them in Omonia and release them in Anavyssos [online], 10 June. Available from: http://www.protothema.gr/greece/article/?aid=285090 [Accessed 15 June 2015].

Strik, T., 2013. Migration and asylum: mounting tensions in the Eastern Mediterranean [online], 23 January. Available from: http://www.refworld.org/docid/51384f992.html [Accessed 28 May 2015].

Swarts, J. and Karakatsanis, N.M., 2012. The securitization of migration: Greece in the 1990s. Journal of Balkan and Near Eastern studies, 14 (1), 33-51.

Tsironis, D., et al., 2009. Guarding land and sea borders and illegal migration in Greece and the European Union. Dissertation (MA). Hellenic National Defence College, Greece.

Tsoukala, A., 2006. Democracy in the light of security: British and French political discourses on domestic counter-terrorism policies. Political studies, 54 (3), 607-627.

Wacquant, L.J.D., 1989. Towards a reflexive sociology: a workshop with Pierre Bourdieu. Sociological theory, 7 (1), 26-63.

Wæver, O., 1995. Securitization and desecuritization. In: R. Lipschutz, ed. On security. New York: Columbia University Press, 46-86.

Williams, M.C., 2007. Culture and security: symbolic power and the politics of international security. London: Routledge. 